$\sqrt{3}$

J. bio-sci. 15: 77-82, 2007

ISSN 1023-8654

http://www.banglajol.info/index.php/JBS/index

\title{
ISOLATION AND CHARACTERIZATION OF RHIZOSPHERE BACTERIA AND THEIR EFFECT ON GERMINATION OF RICE SEEDS AND GROWTH OF SEEDLINGS
}

\author{
Shamima Nasrin ${ }^{1}$ and M A Rahman ${ }^{2}$ ? \\ Department of Botany, University of Rajshahi, Rajshahi-6205, Bangladesh
}

\begin{abstract}
Rhizosphere bacteria were isolated from root zones from rice fields. These were cultured in laboratory conditions and investigated the effects on germination and growth of rice seedlings. They inhabit around the roots and live on root exude and benefit the plants by altering the solubility and availability of mineral nutrients and protecting the roots from invasion of pathogens by creating an antibiotic barrier around the root. It has been found that rhizosphere bacteria have no effect on germination of rice seeds. Both the rhizosphere bacteria and the Agrobacterium have been found to produce better growth of rice seedlings in pot cultures but later is less effective than the former. Rhizosphere bacteria are mixtures of many e.g. Actimomyces, Proteobacteria, Pseudomonas etc. but Agrobacterium sp is single.
\end{abstract}

Key words: Rhizosphere, Bacteria, Symbiosis, Soil microflora, Non-leguminous plants.

\section{Introduction}

Symbioses between leguminous plants and bacteria stimulated interests to study microflora of the soil in the 19th century. This led to inoculate non-leguminous plants, profitably with plant roots led to the definition of the ecological region around plant roots as the Rhizoshpere. The German microbiologist Hiltner (1904) introduced the term rhizosphere to denote their soil region for enhanced microbiological activity immediately around the plant root, which he was first to demonstrate. Subsequently root-influence upon the soil microflora has been recognized into two zones: (i) the root surface and (ii) the rhizosphere. Thom and Smith (1938-39) defined the rhizosphere as that ball of earth filled by roots of particular plants with the microorganisms that accompany them.

Knowledge œncerning the microflora of the root gradually developed during the early 20th century (Clarke 1949). Bacteria associated with roots affected plant welfare, particularly by altering the solubility and availability of mineral nutrients. Starkey (1938) was able to distinguish two sources of nutrients provided by the roots to rhizosphere bacteria: (i) soluble excretions, (ii) sloughed-off dead root cells.

Rhizosphere is a zone between the root surface and the soil adjacent to the roots. The bacteria which live in this zone may remain in the soil that adheres to the roots after gentle shaking. The bacteria inhabiting in the rhizosphere are called rhizobacteria. They live on the surface of roots in the soil and form a barrier to the root infecting parasites (bacteria, fungi, actinomycetes, nematodes etc). Rhizobacteria excrete antibiotic substances, thereby protecting the roots from plant parasites by the toxic effects (Ferris et al. 1992). In exchange they get their nutrition from the root exudates. Thus symbiotic relationship is established between the host plant roots and the rhizosphere bacteria.

\footnotetext{
? To whom all correspondence should be addressed. 200/ Padma R/A, Road \# 4, Rajshahi-6207.
} 
Ethylene-producing rhizosphere bacteria Pseudomonas sp., Enterobacter sakazakii and Klebsiella oxytoca control root parasite striga-infestation in maize and sorghum Babalola et al. 2002). However, most of rhizobacterial toxins are antibiotic in nature.

It was recognized that the rhizosphere population might compete directly with plants for mineral nutrients that were of short supply. Nevertheless, unequal stimulation by roots of different microbial types and also that the kind of plant, the age and the rhizosphere. All are in agreement that a denser microbial population exists in the rhizosphere than in the soil apart from the root. Its effect on the soil population is often expressed as the $\mathrm{R} / \mathrm{S}$ ratio, that is, the number of organisms in rhizosphere soil $(\mathrm{R})$ as compared with the number in the same soil (Non- rhizosphere) beyond the influence of the roots.

Microflora in rhizosphere soil is higher than the soil without rhizosphere indicates the influence of living roots in the soil. One such a physiological group, the ammonifying bacteria related to the capacity of mineralizing the nitrogenous materials by bringing about a rapid decomposition of organic nitrogen in the rhizosphere.

The present work has been undertaken to isolate and characterise the bacteria from the rice field rhizosphere. Fresh cultures of rhizosphere bacteria were inoculated in the sterile soil in pot cultures of young seedlings of rice to see the effect of these bacteria on germination of rice seeds and their contribution to growth of seedlings.

\section{Material and Methods}

Rhizosphere bacteria were obtained by isolation from rice field rhizosphere and pure culture of Agrobacterium sp were obtained from the laboratory of the Department of Botany, University of Rajshahi. Fresh and dried seeds of rice were used for germination and raising the seedlings.

Media are the synthetic mixtures of bacto-peptone $10 \mathrm{~g}, \mathrm{NaCl} 5 \mathrm{~g}$, Yeast ext. Powder $0.5 \mathrm{~g}$ in a liter of distilled water, Agar powder of $105 \mathrm{~g}$ was added in $100 \mathrm{ml}$ for solidification of liquid medium. These were used for culturing the bacteria in glass-tubes and in petri dishes, The media were sterilized in an autoclave at $120^{\circ} \mathrm{C}$ under 15lbs pressure for $15 \mathrm{~min}$. Both solidified and liquid culture media were used for study of rhizosphere bacteria. Soil samples were collected from rhizosphere soil from a rice field. Soils from $6 \mathrm{~cm}$ radius from the tillering rice plant and $6 \mathrm{~cm}$ depth from the surface were collected and sun dried. Pots were filled with these soils and filter papers were put appressed on the soil and sterile liquid bacterial culture medium was pipetted on the filter paper to allow growth of bacteria in colonies on the filter paper from the soil. The pots were put on the laboratory bench at room temperature $(30-350 \mathrm{c})$. Well-grown bacterial colonies were picked up with a sterile wire loop and cultured separately in liquid culture tubes. These were numbered numerically. Streaking method was used for making bacterial cultures in plates.

Rice seeds were germinated on water soaked filter paper in sterile method culture in petri dishes and seedlings of 5-day old were transplanted in pots to grow them by sterile sand or soil culture method as the case may be. Sand and soil were sterilized at $120^{\circ} \mathrm{C}$ under $15 \mathrm{lbs}$ pressure for one hour, then cooled. The pots were filled with sterile sand or soil as the purpose of the experiments and the seedlings were transplanted in them.

\section{Results}

Rice seeds were spread on filter papers in petri dishes and soaked with sterile water to find out the viability and germination of seeds. Time to time watering was done to keep wet the filter paper to allow germination. Experiments were set up in the one set of three as control, the second set of three srayed with 
Agrobacterium and the third set of three sprayed with rhizosphere bacteria to see their effects on germination of seeds. After 4-5 days, it was found that 100 percent germination of seeds in the control as well as in those treated with bacteria showing no effects of bacteria on germination.

For pot culture experiments with sterile sands for sand culture experiments and sterile soil for soil culture experiments, five pots were used for each set of experiments. Seedlings of equal length of same age were taken and one seedling was planted in each pot at the center. Adequate watering with equal amount of NPK solution was applied in each pot for nutrition and water requirements of the seedlings. Fresh cultures of bacteria were used for preparation of bacterial suspension in sterile distilled water. Spraying was done with Agrobacteria in 5, rhizosphere bacteria in other 5 and only sterile distilled water in the rest five pots (control). These were put in the garden for growth of seedlings.

Table 1. Number and length of leaves and roots per seedling without bacterial treatment.

\begin{tabular}{|c|c|c|c|c|c|c|c|}
\hline $\begin{array}{l}\text { Pot } \\
\text { No }\end{array}$ & $\begin{array}{c}\text { No. of } \\
\text { leaves/plant }\end{array}$ & $\begin{array}{l}\text { Length of } \\
\text { leaves } \\
(\mathrm{mm})\end{array}$ & $\begin{array}{l}\text { Average } \\
\text { Length of } \\
\text { leaf }(\mathrm{mm})\end{array}$ & $\begin{array}{l}\text { No. of } \\
\text { Tillers }\end{array}$ & $\begin{array}{l}\text { No. of } \\
\text { roots/plant }\end{array}$ & $\begin{array}{l}\text { Total Length } \\
\text { of roots/plant }\end{array}$ & $\begin{array}{l}\text { Average } \\
\text { Length of } \\
\text { root (mm) }\end{array}$ \\
\hline 1 & 6 & 25 & \multirow{5}{*}{21} & 0 & 48 & 82 & 1.70 \\
\hline 2 & 6 & 24 & & 0 & 49 & 80 & 1.63 \\
\hline 3 & 4 & 9 & & 0 & 46 & 79 & 1.71 \\
\hline 4 & 8 & 25 & & 2 & 42 & 75 & 1.78 \\
\hline 5 & 5 & 22 & & 2 & 43 & 78 & 1.61 \\
\hline
\end{tabular}

Table 1 shows the results of the control. Numbers of leaves are five to six per seedlings with an exception in pot 3 where the leaves are also shorter $(9 \mathrm{~mm})$. We see 2 tillers in pot 4 and 5 .

Table 2. Number and length of leaves and roots per seedling after Agrobacterial treatment.

\begin{tabular}{|c|c|c|c|c|c|c|c|}
\hline $\begin{array}{l}\text { Pot } \\
\text { No }\end{array}$ & $\begin{array}{c}\text { No. of } \\
\text { leaves/plant }\end{array}$ & $\begin{array}{c}\text { Length of } \\
\text { leaves } \\
(\mathrm{mm})\end{array}$ & $\begin{array}{l}\text { Average } \\
\text { Length of } \\
\text { leaf }(\mathrm{mm})\end{array}$ & $\begin{array}{l}\text { No. of } \\
\text { Tillers }\end{array}$ & $\begin{array}{l}\text { No. of } \\
\text { roots/plant }\end{array}$ & $\begin{array}{l}\text { Total Length } \\
\text { of roots/plant }\end{array}$ & $\begin{array}{l}\text { Average } \\
\text { Length of } \\
\text { root }(\mathrm{mm})\end{array}$ \\
\hline 1 & 15 & 45 & \multirow{5}{*}{36.8} & 2 & 52 & 80 & 1.54 \\
\hline 2 & 20 & 31 & & 4 & 58 & 81 & 1.40 \\
\hline 3 & 15 & 32 & & 2 & 50 & 89 & 1.78 \\
\hline 4 & 18 & 41 & & 3 & 52 & 84 & 1.62 \\
\hline 5 & 17 & 35 & & 2 & 51 & 82 & 1.61 \\
\hline
\end{tabular}

Table 2 shows the results of Agrobacterium treated pot cultures. The leaves are many (15-18). All the mother plants produced tillers.

Table 3 shows the results of Rhizosphere bacteria treated pot cultures. The leaves are many (15-21) as in Agrobacterium treated experiments with an exception in poł2 where we find 31 leaves. Tillers are more or less same in number as in Agrobacteria treated plants. Number of roots and their length are more than those of Agrobacteria treated plants. Photographs were taken after 3 weeks (Figs 1 and 2). Data were scored after two months from each group of seedlings (Table 3 ). 


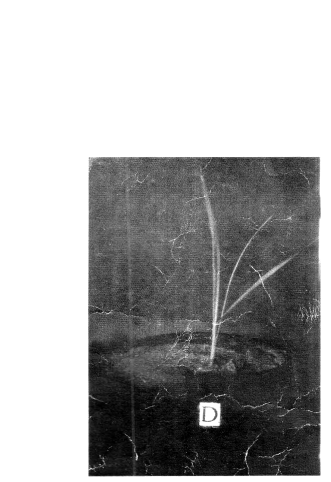

Control

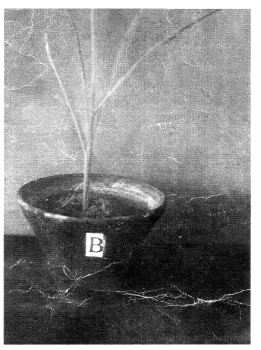

With Rhizosphere Bacteria

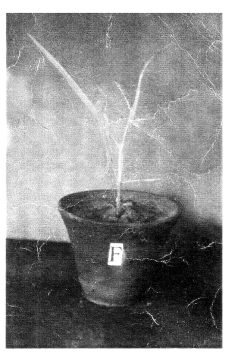

With Agrobacterium

Fig.1. Sand Culture

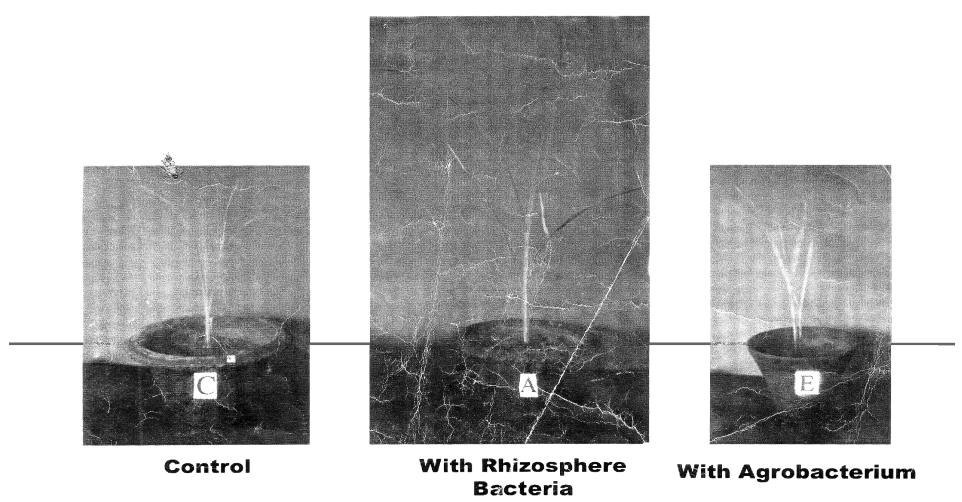

Fig 2. Soil Culture

Table 3. Number and length of leaves and roots per seedling after Rhizosphere bacterial treatment

\begin{tabular}{|c|c|c|c|c|c|c|c|}
\hline $\begin{array}{l}\text { Pot } \\
\text { No }\end{array}$ & $\begin{array}{c}\text { No. of } \\
\text { leaves/plant }\end{array}$ & $\begin{array}{c}\text { Length of } \\
\text { leaves } \\
\text { (mm) }\end{array}$ & $\begin{array}{l}\text { Average } \\
\text { Length of } \\
\text { leaf }(\mathrm{mm})\end{array}$ & $\begin{array}{l}\text { No. of } \\
\text { Tillers }\end{array}$ & $\begin{array}{l}\text { No. of } \\
\text { roots/plant }\end{array}$ & $\begin{array}{l}\text { Total Length } \\
\text { of roots/plant }\end{array}$ & $\begin{array}{l}\text { Average } \\
\text { Length of } \\
\text { root }(\mathrm{mm})\end{array}$ \\
\hline 1 & 21 & 49 & \multirow{5}{*}{44.6} & 4 & 40 & 96 & 2.40 \\
\hline 2 & 31 & 45 & & 5 & 68 & 89 & 1.31 \\
\hline 3 & 15 & 46 & & 2 & 58 & 85 & 1.47 \\
\hline 4 & 16 & 45 & & 2 & 40 & 86 & 2.15 \\
\hline 5 & 12 & 38 & & 2 & 32 & 98 & 3.06 \\
\hline
\end{tabular}


The photographs (Figs 1 and 2) show that either in sand culture or in soil culture the seedling growth is much better with the rhizosphere bacteria in comparison with those in the control and also of those with Agrobacteria. This we consider due to the symbiotic effect of rhizosphere bacteria with the seedlings.

Rhizosphere bacteria were re-isolated from the rhizosphere sands and soils of pot cultures of young seedlings with the help of sterile wire loop by touching the roots and sand/soil around the roots. However, no bacteria were obtained from the control pot cultures.

\section{Discussion}

Roots anchor the plants with the soil and draw nutrients from it. Manuring and adequate watering are needed for maintaining the fertility of the soil. Apart from these factors, microorganisms are very important constituents of the soil. Hardly there is any soil without microorganisms, mainly the bacteria. The microflora in the soil benefits to the plants by protecting the roots from infection of pathogenic bacteria, fungi and other parasites. Plant roots excrete organic substances, although in smaller amounts, in the soil around the roots. These includes sugars, organic acids, amino acids and vitamins which stimulate the development of microflora of non-nitrogen fixing microorganisms rather than of Azotobacters and Clostridia which require a selecive nitrogen free medium for enrichment. It is assumed that the root exudes of different plants differ considerably in their Carbon/ Nitrogen ratio. Leguminous plants, for instance, excrete relatively large amounts of $\mathrm{N}$-containing compounds, particularly amino acids, whereas sugar cane and sugar beets excrete relatively large amount of sugars. If this assumption is correct, it is expected that (a) Azotobacters respond to root exudes having a high $\mathrm{C} / \mathrm{N}$ ratio. When the roots are growing in heavily buffered alkaline soil that (b) other types of soil Nitrogen fixers which are not repressed by an acid reaction (Clostridia, Azotobacters and perhaps, Pseudomonas) are selected in the rhizosphere (Clarke 1949). Rhizosphere microoganisms produce beneficial effects on plants by fixation of molecular nitrogen by their solubilizing and chelleting effects on diverse mineral nutrients. By the extent to which they did on the roots in the absorption and storage of mineral nutrients by their synthesis of accessory growth substances and by their suppression or control of soil borne plant pathogen (Garrett 1960).

Agrobacterium $s p$ is closely related to some members of the genus. The interesting features of this relationship is that where Rhizobium infects plants and causes the formation of root nodules, Agrobacterium $s p$ causes a tumor like growth in plants called crown gall tumor.

In our experiments with rice seedlings the growth was enhanced and produced tillers with Agrobacterium as well as with other rhizosphere bacterial mixtures compared with the control, indicating beneficial effect of rhizosphere bacteria. We are convinced that the rhizosphere bacterial mixtures are more efficient than the single rhizosphere bacterium as in our experiments with the Agrobacterium alone. We are also convinced that further work in this line with large-scale experimental work in fields, also with other crops will bring about improvements in our agriculture by minimizing application of organic manure and chemical fertilizers. Rhizosphere bacteria may, therefore, be used as a substitute for fertilizer, because along with the roots they produce $\mathrm{CO}_{2}$ around the roots by respiration and this in turn is converted to carbonic acid with water $\left(\mathrm{CO}_{2}+\mathrm{H}_{2} \mathrm{O}=\mathrm{H}_{2} \mathrm{CO}_{3}\right)$. Carbonic acid converts the nutrients of the soil to the soluble form for absorption by roots (Berkeley 1971). Organic manuring does not harm the rhizosphere flora. Moreover, application of rhizosphere bacteria in the soil increases the crop yield (Katznelson, 1965).

Hirano et al. (2001) isolated rhizosphere bacteria from a field treated long-term with agrochemicals (conventional farming; C F) and from a field free of agrochemicals (nature farming; N F) and found that many of them were similar but some (B-Proteobacteria) differed in their 16S/rDNA sequencing. However, all of 
them are known to promote the growth of rice plant. The contribution of nitrogen fixing bacteria to rice growth is not clear. Therefore, the findings of Hirano et al. (2001) present a clear evidence of promoting growth of rice plant by non-nitrogen fixing rhizosphere bacteria.

\section{References}

Babalola O O, Elie O Osir and Abiodun I Sanni (2002) Characterization of potential ethyleneproducing rhizosphere bacteria of Striga- infested maize and sorghum. African journal of Biotechnology 1 (2): 67-69.

Berkeley R C W (1971) Microbiology of soil. Micro-Organisms: Function, Form and Environment. Edward Arnold (Publishers) Ltd. pp. 725

Clarke F E (1949) Soil Microorganisms and plant roots. Advance Agronomy 1: 241-288.

Ferris A and Jaffe B A (1992) Beyond Pesticides. Biological Approaches to Management in California. Incomplete ref?

Garrett S D (1960) Biology of Root-infecting Fungi. Cambridge University Press. pp. 293.

Hiltner L (1904) Uber neuere Erfahrungen und Probleme ouf dem Gebiet der Bodenbakteriologie und unter besonderer Beruck sichtigung der Grundungeng and Brache. Arb. dtsch Lundvt-Ges 98, 59; R

Hirano K, Hyatsu M, Nioh I and Nakai HI (2001) Comparison of Nitrogen fixing Bacterial Flora of rice Rhizosphere in the fields Treated Long-term with agrochemicals and Non-agrochemicals. Microbes and Environments 16: 155-160.

Katznelson H (1965) Recent studies of the Rhizosphere Phenomenon. 7th International Congress of Soil Science. 2 : 537-544.

Starkey R L (1938) Some influences of the development of higher plants upon the microorganisms in the soil VI. Microscopic examination of the rhizosphere. Soil Science 45: 207-49.

Thom C and Smith N R (1938-39) Fauna and Flora of the Soil. Agriculture year book Washington D. C. pp 942. 